ISBN 978-81-936279-8-3

12th International Conference on Gender studies, Education, Business and Disaster Management

(GEBDS-18)

London (UK) June 25-26, 2018

\title{
Chinese Dragon's Rise in the Global Film Industry
}

\author{
Preethi Amaresh \\ University of Madras, India
}

\begin{abstract}
China, the name synonym with unstoppable economic progression has also made similar impact on the entertainment industry. This entertainment sector is now viewed as the tool for establishing Chinese influence all over the world.Chua, A Singapore Scholar in 2012 coined the term "Soft Power Competition" on how East Asian countries use popular culture to gain a presence or influence in other countries. From economic power to a world power, the translation and transformation requires 'soft power' peddling which is carried out with help of these entertainment sector. These are often referred to as 'cultural industries' which projects the Chinese culture to other nations.

Chinese films are one of three distinct historical threads of Chinese-language-films together with the HongKong cinema and the Taiwan Cinema. It is estimated that the China has the second largest movie box office in the world. And in the era of economic decisions, it is no wonder that Hollywood's producers understand this and make their movies suited to the Chinese market and censors. China too is looking at the Hollywood to forge a fruitful creative collaboration. Chinese movie screens have been increasing exponentially. At present, China has more cinema screens than USA, making it now the largest movie market in the world. And currently, China's movie ticket sales are second only to the U.S. It is estimated that by 2020 China will surpass the Hollywood to become the biggest movie market in the world.

The 3 ways the U.S makes it to the Chinese market is through Revenue sharing, Co-producing with a Chinese company and payinga flat fee. After China became a part of WTO, China has increased the foreign movie quota to 34 films per year. It is considered that the winning formula is combining Hollywood and China. And in order to achieve this, one needs to understand the Chinese culture and its sensitivities and the effectively study the market to cater to the requirements of the audience.Currently the Indian-Bollywood is also eyeing collaboration with its Chinese counterparts. With shared cultural values and history, there is no doubt that there is a potential market combining India and China.

Film is an art form that attracts both elderly and youth. Cinema is beyond world of politics. It speaks its own language, a universal language of emotions. Cinema should be an emotional endeavour and not a political endeavour. Globalization is inevitable and postive. There will be big blurring of borders and films are an example. With the success of Chinawood Hollywood in Oscars 2018 and the opening of the World's largest movie studioQingdao Movie Studiorecently which aims to bring the global film community together to work with various countries, Its interesting to look forward to how China as a tool of soft power can influence the world through cinemas.
\end{abstract}

Keywords: Soft power competition, Belt and Road Initiative, Globalization, Qingdao Movie Studio, Silk Road, Cultural industries, Revenue Sharing, Co- Production and Flat fee.

\section{Introduction}

Chua, A Singapore Scholar in 2012 coined the term "Soft Power Competition" on how East Asian countries use popular culture to gain a presence or influence in other countries.China- the name synonym with unstoppable economic progression has also made similar impact on the entertainment industry. The medium of entertainment of cinema was introduced to the mainland in the year 1896. This entertainment sector is now viewed as the tool for establishing Chinese influence all over the world. From economic power to a world power, the translation and transformation requires 'soft power' peddling, which is carried out with help of this entertainment sector. These are often referred to as 'cultural industries' which projects the Chinese culture to 
other nations. Hence, the influence of the 'cultural industries' is an important aspect which needs to be studied in-depth, in order to understand level of growing influence of china as a global super power.

China's rise is the economic story of 21 st Century and the entertainment industry is no exception. Cinema was introduced in 1896 in China. The film industry is being viewed as part of China's modernisation process. With the global influence wielded by the country's economy, the rise of "Cultural Industries" in China is seen as the next step along a path from developing nation to world power. Chinese films are one of three distinct historical threads of Chinese-language-films together with the Hong-Kong cinema and the Taiwan Cinema. Soon after Invasion of Japan in China and the occupation of Shanghai, the industry in the city was severely retrenched, with filmmakers moving to Hong-Kong and other places. The film industry continued to develop after 1945 until the Cultural Revolution. With China's liberalisation in the late 1970s and its opening up to foreign markets commercial considerations made its impact in post-1980s filmmaking. ${ }^{\text {i }}$

\section{Chinawood on Hollywood}

China has the second largest movie box office in the world. So it's no wonder that Hollywood panders to Chinese audiences and censors. China has been eyeing Hollywood to strengthen its entertainment holdings and forge creative collaborations. China has built 27 screens per day on an average in 2016. In November'16, China had more cinema screens than the U.S. According to Ent group via quartz, in 2017 China's box office revenue is expected to surpass the U.S making it the largest movie market in the world. Currently, China's movie ticket sales is second only to the U.S. In 2002, Zhang's "Hero" was yet another International success. "The Great Wall," a US-China co-production directed by Zhang Yimou, starring Matt Danon, and released in theaters today, is the most expensive Chinese film to date.

According to Economist via Mc Kinsey \& Company, the growth of middle class has created a massive new market for the entertainment. Over last 20 years U.S has strategically operated positive Chinese story elements to bolster their chances in one the films selected. In the movie "Red Dawn", the enemy was originally China but they changed to North Korea. In the movie "2012", actor Oliver Platt in the last 10 minutes praised China for building arcs in a short span of time. He said "Leave it to the Chinese". The 3 ways the U.S makes it to the Chinese market is through Revenue sharing, Co-producing with a Chinese company and payinga flat fee. ${ }^{\text {ii }}$

\section{China's film industry in the next 10 years?}

China has money to spend on Hollywood and this incredible market at home. This China-Hollywood connection will sustain itself for a long time. China's box office weight has already affected the kind of films Hollywood makes. Pleasing Chinese audiences and a Chinese central government hyper allergic to criticism is now part of the Hollywood formula. In 2015, growth of film industry increased from 5\% to $15 \%$. In $\mathbf{2 0 1 7}$, it is expected to grow at a sustainable rate of $15 \%$ per year. By 2018, it is expected to surpass U.S to become the biggest. By 2026, it is expected to hold a stake of $40 \%-50 \%$ of global market share. As China continues its urbanisation, as the number of shopping malls grows and income of population increases, film market will maintain a fast growth rate over the next 10 years. ${ }^{\text {iii }}$

\section{Elements in Chinese movies}

The first element is the natural wonders to be found in China, represented by the top grossing movie ever, "Avatar" directed by James Cameron. Despite the digital technology used in the film, this apparent environmental utopia can be found in Zhang Jia, Hunan province (mid-north China).The second element is the various types of buildings with strong Chinese traditional characters commonly built several years ago like a temple, imperial palace or residential houses. In the movie "Mission Impossible" Tom cruise is running on the roofs and corridors of many residential houses in a chase scene. The third element is the contemporary buildings which have famously sprung up all over urban China generally located in Hong Kong, Shanghai or Beijing. They symbolise modern China with prosperous development since the beginning of modernisation and 
economic liberalisation. The last element is the Space X and Hollywood blockbuster "The Martian" is proof that Americans want to see the United States and China cooperate in space, but lamented Washington's ban on collaboration between the two countries. Movies like the Gravity and the Independence Day (Resurgence) are few more examples of this element.

\section{Wanda's Qingdao Studio Metropolis: Hollywood of the East?}

Qingdao's temperate climate and coastal setting almost 350 miles north of Shanghai lends it an atmosphere that more strongly recalls Southern California. On a steep green hillside that overlooks the yellow sea, one will find a gigantic sign with white free standing characters 东方影都 which translates literally as "Eastern Cinema". It's like the Hollywood sign that overlooked Los Angeles since 1923, only bigger. The studio was built on 1,200 acre site, where the construction Qingdao oriental movie metropolis, a vast development that includes a movie studio, a theme park and entertainment centre, a 4,000 room resort hotel complex, a shopping mall, a 300 berth yatch club, a celebrity wax museum and a hospital. The Dalian Wanda group, China's biggest commercial estate developer and the world's largest owner of movie theatres has committed $8.2 \$$ billion to the project which will open its doors in April, 2017. The Wanda Group also wants to expand internationally their mission to connect the west to the east. The goal of inviting the entire global film making industry is ambitious. The metropolis will have its own International film festival. An opportunity to bridge two great cultures in a rapidly changing world.

\section{Intellectual Property Rights and films in China}

China's strict regulation of entertainment imports, including foreign films, violates the country's World Trade Organization (WTO) commitments, as determined in a 2007 WTO decision calling for China to open its film market to foreign films. The Chinese IP system has developed rapidly over the past 30 years. But a number of differences remain between international norms and Chinese film industry and IP system. Industries in which China will accept foreign investment or business operations are limited. Foreign investment in Chinese industries is categorised as "Encouraged", "Permitted","Restricted", "Prohibited". Foreign involvement in films and Television business is currently categorised as "Restricted". In keeping with the "Restricted" categorisation of the film sector, foreign companies are not permitted to engage independently in production in China. China has adopted an increasingly modern intellectual property legal framework following accession to the WTO in 2001 and the signing of a number of other International IP treaties. On going revisions to the Chinese copyright law are adding another layer of sophistication and aim to bring the Chinese copyright system closer to international norms. Copyright ownership in joint films production agreements are not as clear in China as in other jurisdictions and should be negotiated on a project by project basis. Chinese contracts are usually simpler and shorter than contracts in developed countries. China's new film law forbids local foreign film makers intent on "Damaging China's national dignity, honour and interests or harming social stability or hurting national feelings which is quite an expansive list of no-nos. ${ }^{\text {iv }}$

\section{How Hollywood will engage and benefit from Chinese market's high speed growth?}

Hollywood needs to strengthen collaboration with Chinese companies. A need to understand Chinese market and to earn profit from that market. To fill the gap of understanding, the best way is for U.S companies to increase their collaboration with Chinese companies through financial deals, production deals or collaboration on film techniques. Improve the quality of Hollywood films. According the reports, Chinese industry is a student and Hollywood is the teacher. How can a student instruct a teacher on how to improve?. Hollywood is famous for its story telling techniques. But now its fading. Many films are just sequels based on original intellectual properties. Hollywood sometimes relies more on technology and visual factors rather than a good story which has contributed to its films decreased success in the Chinese market in recent years. To participate in the growing Chinese market one must improve film quality and be a good story teller. Qingdao movies metropolis 
actually increases employment opportunity for Hollywood. QMM is a massive project. There is substantial hardware but China lacks management skills and technical talents which we consider "Software". So they are recruiting technology experts and operation managers globally especially from Hollywood. For technical talent who don't find their way in Hollywood can find ways to make a better living in QMM. Wanda and Qingdao government offer very generous incentives that will lead to cost savings for Hollywood and higher profits. QMM is an opportunity, not a competitor. ${ }^{\mathrm{V}}$

Financial woes, haven't stopped Le Vision head Zhang Zhao, a one time philosophy major who runs a major Chinese entertainment company from demanding Hollywood's respect. He says that when he went to the U.S 20 years ago and worked as a delivery boy, learned English, he questions as to why Hollywood people who come to China can't speak in Chinese. Hollywood for him should treat both like an equal partner and not just a market.

\section{Chinawood on Bollywood}

Looking back into the History, both India and China have had strong cultural ties for ages. Despite the major political differences China and India share a great deal of shared culture DNA between them. Both Bollywood and Chinese film industry have been preoccupied with the west rather than east. China has been making its global impact on Hollywood. In 2013, India and China decided to strengthen bilateral cooperation in film and broadcasting sector and China was the principal guest country at the India International Film Festival which was held in Goa in November. In 2014 agreement, India-China planned to improve market for Indian movies and vice versa. Delhi and Beijing announced 3 movies through co-production which paves way for greater cultural exchange. The idea is to dilute rather than crude the Chinese stereotypical characters in Indian films. "Lost in India" movie is set to boost to tourism in India by the Chinese just like it boosted the tourism in Thailand after "Lost in Thailand" was released.

\section{Belt and Road initiative and Film Industry}

Recently the Qingdao movie studio joined the Belt and Road initiative (BRI). BRI is a natural export market for China growing film industry. ${ }^{\mathrm{vi}}$ The 2017 Beijing International Film festival screened 13 films from BRI countries including Poland, Iran and Philippines. China National Film Museum will work with other BRI countries to hold annual film events including awards, screening and exhibitions. This initiative has boosted China's film industry and will drive its next boon. Korgos port, a Central station for Silk Road is home to over 600 film companies, many of which are owned by major Chinese film franchises and directors. The city epitomizes the development of film industry along BRI. Chinese actress XuDabao even wore a dress designed like a Chinese flag at Cannes film festival to show support for the initiative ${ }^{\text {vii }}$ China's Shinework media has an entire BRI slate of productions planned with producers from countries along the route. China is finishing filming on composer Xian Xinghai, the $1^{\text {st }}$ co-production between China and Kazakhstan. The movie is about the composer who worked in Kazakhstan as a sign of the countries history of trade and co-operation. The film was inspired by a speech delivered by Xi Jinping. China wants to establish people to people bond through film festivals and film production. China wants to light up Silk road themes. Communication between these countries in terms of films has just begun. But once the hardware is ready, the cultural impact will follow. The silk road online film festival helps independent film makers to raise their visibility through the web for a limited time during the online festival. Silk road on demand platform can supports and promotes BRI in collaboration with Silk road International film festival. ${ }^{\text {viii }}$ Shanghai film festival received the application of nearly 2,500 films from 106 countries including 1,100 films submitted by film makers and institutions from 50 countries and regions along BRI. Many films made by Malaysia, Philippines, Afghanistan, Serbia, Romania are incorporated into BRI special presentations. ${ }^{\mathrm{ix}}$ The 2017 Beijing film festival made a special presentation on BRI theme where documentaries featuring large will animals, tiny kingdoms made the debut. According to a Peking University professor, the BRI will spark the next boom in the Chinese film industry. ${ }^{x}$ 


\section{References}

$[1]{ }^{\mathrm{i}}$ The Chinese cinema industry: China's cultural revolution, Independent, 2006 (http://

[2] www.independent.co.uk/news/world/asia/the-chinese-cinema-industry-chinas-cultural-

[3] revolution-6112577.html)

[4] ${ }^{\text {ii }} 9$ Utterly Fascinating Ways The Chinese Movie Industry Is Changing Entertainment, David Harrison, (http://www.ranker.com/list/ways-chinese-movie-industry-changes-entertainment/david-harrison).

[5] ${ }^{\text {iii }}$ Is Chinawood the new Hollywood, Clarissa, 2016(http://www.bbc.com/culture/story/20140207- is-chinawoodthe-new-hollywood).

[6] ${ }^{\text {iv }}$ Directed by Hollywood, Edited by China: How China's Censorship and Influence Affect Films Worldwide, Armstrong and Cooner, 2015 (https://www.uscc.gov/sites/default/files/Research/ Directed\%20by\%20Hollywood\%20Edited\%20by\%20China.pdf).

[7] ${ }^{\vee}$ China's Film Industry: A Blockbuster in the Making, Wharton, University of

[8] Pennsylvania, 2016 (http://knowledge.wharton.upenn.edu/article/lights-china-action-how-china-is-getting- intothe-global-entertainment-business/)

[9] ${ }^{\mathrm{vi}}$ China uses film to sell its massive One Belt, One Road -initiative, The Australian, 2018,(https://www.theaustralian.com.au/arts/china-uses-film-to-sell-its-massive-one-belt-one-roadinitiative/news-story/5776cbb029315c77b3bbec0a0567c5aa)

[10] ${ }^{\text {vii }}$ International Alliance Set to Support "Belt and Road" Movie Production, Screen Training Ireland, (https://www.screentrainingireland.ie/news/international-alliance-set-to-support-belt-and-road-movieproduction/)

[11] ${ }^{\text {viii }}$ China plans US\$2 billion film studio and 'One Belt, One Road' theme park, South China Morning Post, 2016. (http://www.scmp.com/news/china/society/article/2049735/china-plans-us2-billion-film-studio-and-one-belt-oneroad-theme).

[12] ${ }^{\text {ix }}$ China recreates the silk road to challenge Hollywood, The Wall Street Journal, 2017. (https://www.wsj.com/articles/china-recreates-the-silk-road-to-challenge-hollywood-1514390400)

[13] ${ }^{\mathrm{x}}$ Belt and Road Initiative boosts China's film industry, China Daily, 2017, (http://www.chinadaily.com.cn/business/2017-05/13/content_29333589.htm) 